\title{
プラスチックフィルム熱接合部の特性評価
}

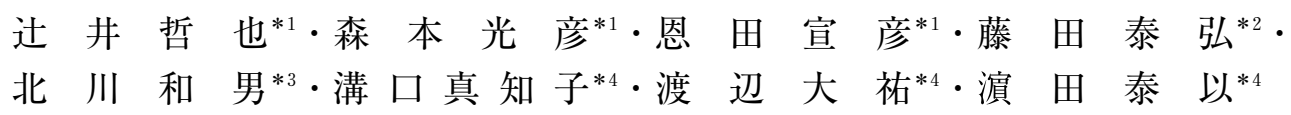

\section{Evaluation of Properties of Heat Sealed Parts in Plastic Films}

\begin{abstract}
Tsujii, Tetsuya*1/Morimoto, Mitsuhiko*1/Onda, Nobuhiko*1/Fujita,Yasuhiro*2/ Kitagawa, Kazuo*3/Mizoguchi, Machiko*4/Watanabe, Daisuke*4/Hamada, Hiroyuki*4

As a packaging material, plastic film is widely used in daily life to protect merchandise while improving their marketing appeal. There are many cases when the plastic film packaging is formed into bags by heat sealing the edges. In order to discuss the properties of the heat-sealed portion of these plastic film bags, oriented polypropylene film (OPP) and cast polypropylene film (CPP) were heat-sealed, and the strength and crystalline structure of the heat sealed regions were investigated. The strength was obtained from peel tests according to JIS Z 1707 and from tensile tests for circular notched specimens. The crystalline structure was analyzed by differential scanning calorimetry (DSC) and Fourier transform infrared spectroscopy (FT-IR). The crystallinity of the heat-sealed part affected the tensile strength. When the crystallinity of OPP was high, the strength obtained from the tensile test for circular notched specimens was high, and the relation between crystallinity and the strength could be established.
\end{abstract}

Key words : Heat seal/Peeling test/Tensile specimen with circular notch/ Differential scanning calorimetry/Fourier transform infrared spectroscopy

\section{1. 緒言}

包装材料としてのプラスチックフィルムは, その使用目 的, 形態, 機能に応じて素材が選択され, 単体フィルムも しくは複合フィルムとして加工されている ${ }^{1)}$.特にラミネー トフィルムは，透明性，柔軟性，熱接合性，ガス透過性， ガス遮断性, 耐熱性, 高強度性などの用途に応じた機能性 を持たせることができ，包装複合材料として開発されてき た2)。また，プラスチックフィルムによる包装は，熱接合 法の普及と発展に伴い, 新しい物流, 新商品の開発や自動 販売などをもたらし, 現在の商品, 製品物流において必要 不可欠な手段，手法となっている.

包装材としての形状は「袋」であることが多く, 袋を作

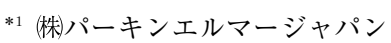

横浜市西区北幸 2-8-4 横浜西口 KN ビル（テ 220-0004） PerkinElmer Japan Co., Ltd.

2-8-4, kitasaiwai, Nishi-ku, Yokohama 220-0004, Japan

*2 サン包装侏

San Package Co., Ltd.

*3 京都市工業試験場 有機材料課

Kyoto Municipal Institute of Technology

*4 京都工芸繊維大学大学院工芸科学研究科

先端ファイブロ科学専攻

Kyoto Institute of Technology 2001.10.19 受理
}

るには何らかの形で端部を接合するというプロセスが必要 である．プラスチックフィルムの接合方法には，機械的結 束法, 接着剂法, 熱接合（ヒートシール）法, 高周波シー ル法，超音波シール法などがある ${ }^{3) 4}$. 一般に袋を作製す る際には, 強度, 生産性, 安全性および環境, リサイクル などの観点から熱接合法が多く用いられている．熱接合は， 流通における取り扱い，特に液体包装においては，使用さ れる時まで破損しない，安定した状態であることが重要な 特性と考えられる ${ }^{6,7)}$. 袋の破損, 破袋の多くは加工され た接合部および接合部を含む部分で生じている 題を検討するために，プラスチックフィルムの熱接合に関 する報告として，新井らのヒートシール強度についての一 連の研究が報告されている ${ }^{8}$. また，二瀬らは破袋部分の ほとんどが接合部に集中していることに着目し, 雲囲気温 度, 引張速度およびシール層の厚みと材質を変えて衝撃引 張試験を行い, フレキシブルパッケージの破袋原因を考察 し，破袋改善の可能性を示している ${ }^{9)}$. C. Mueller らは LLDPEの熱接合において, 変動因子（温度と加熱保持時 間）と接着強さとの関係を検討し， T 字状はく離試験によ り接着強さを評価した。低分子量成分と分岐鎖は容易に接 合面で相互拡散するが，接着面の強化には寄与せず，強い 接合を得るためには，高分子量成分および非分岐成分が融 解するのに必要な温度まで加熱する必要があると示した ${ }^{10)}$. 
Table 1 Temperature of outside and inside of the film in heat sealing

\begin{tabular}{l|c|c|c|c|c|c}
\hline Heat sealing conditions $\left({ }^{\circ} \mathrm{C}\right)$ & 100 & 120 & 140 & 160 & 180 & 200 \\
\hline Temperature of outside of films $\left({ }^{\circ} \mathrm{C}\right)$ & 95.8 & 120.9 & 142.2 & 163.6 & 184.8 & 204.9 \\
\hline Temperature of inside of films $\left({ }^{\circ} \mathrm{C}\right)$ & 78.3 & 97.2 & 115.4 & 136.5 & 153.9 & 177.5 \\
\hline
\end{tabular}

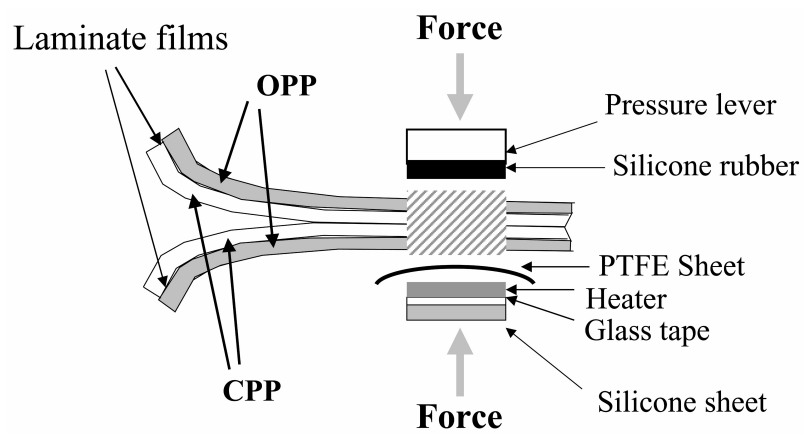

Fig. 1 Sectional view of laminated films in heat sealing

一方，野口らは医療分野において，高圧蒸気下で滅菌処理 がされる滅菌バッグの保管とその強度について検討し，適 切なヒートシール条件の明示が必要であることを述べてい る ${ }^{11)}$.しかしながら，これまでに数多くの熱接合に関する 報告があるが，ほとんどが力学的特性の観点からの考察が 中心であったと思われる.

そこで本研究では，熱接合部および熱接合部を含むプラ スチックフィルムの力学的特性が示すメカニズム, すなわ ち高次構造の変化がその力学的性質に与える影響を示差走 查熱量測定および顕微赤外分光から考察し, 最適な熱接合 成形条件を検討したので報告する。

\section{2. 実験}

\section{1 試験片}

ラミネート基材として, 二軸延伸ポリプロピレンフィル ム（OPP；東洋紡績(株)製パイレンフィルム-OT, P-2161, 厚さ $25 \mu \mathrm{m}$, 以下 $\mathrm{OPP}$ とする）と無延伸ポリプロピレン フィルム (CPP ; 東洋紡績(株)製パイレンフィルム-CT, $\mathrm{P}-$ 1128 , 厚さ $20 \mu \mathrm{m}$, 以下 $\mathrm{CPP}$ とする）を用いた。これら

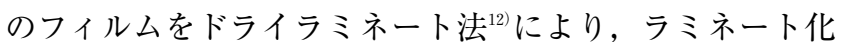
し，OPP/CPP 試験片を得た。 OPP と CPP 間の接着には 2 液混合硬化型のウレタン系接着剂（LX-401 A/SA 60 ; 大日本インキ化学工業(侏製) を酢酸エチルで希釈したもの を用いた. 塗布量 $3.0 \mathrm{~g} / \mathrm{m}^{2}$, 硬化温度 $60^{\circ} \mathrm{C}$ から $80^{\circ} \mathrm{C}$ と した.

\section{2 熱接合装置と熱接合条件}

熱接合装置には，温度制御に優れた富士インパルス株製 OPL-300-10 インパルス式オートシーラーを用いた. 装置 の熱接合部の断面構造と成形方法の模式図を図 1 に示す. 前述のラミネートフィルム 2 枚を CPP 層同士が向き合う ように装置の熱接合部にセットした。熱接合成形条件とし て，最高温度設定を $100 \sim 200^{\circ} \mathrm{C}$ の間で変化させた. 設定 温度到達後の保持時間は 0.1 秒であり, その後室温で冷却 した．熱接合時の圧力は $0.42 \mathrm{MPa}$ に設定した. 図 2 に熱 接合温度 $100,120,140,160,180,200^{\circ} \mathrm{C}$ における温度 特性曲線を示す。温度は熱電対を熱接合装置のシール部で

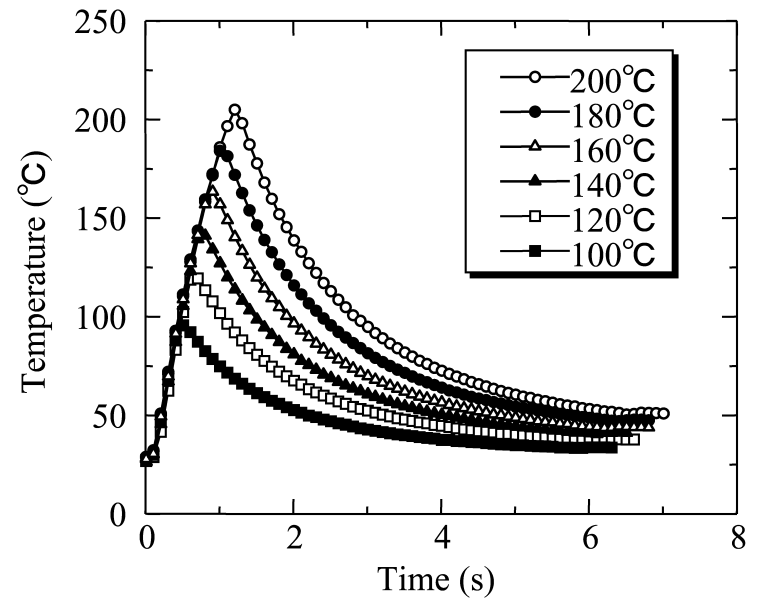

Fig. 2 Temperature profiles of heat sealing

ある熱源側のシリコーンラバーと PTFE シート間に挿入 して計測した．表 1 に設定温度と CPP 面すなわち熱接合 部中央の温度の関係を示す. 設定温度とフィルム内の温度 には差が認められた。 以下, 熱接合温度 $100^{\circ} \mathrm{C}$ とは, 装置 の設定温度を $100^{\circ} \mathrm{C}$ とて接合したことを示す。

\section{3 はく離試験}

はく離試験用試験片とその測定方法の模式困を図 3 に示 す. 熱接合した試験片を幅 $15 \mathrm{~mm}$, 長さ $100 \mathrm{~mm}$ の短冊 状に巻取方向 (MD, 縦方向) と MD に対して直角方向 (TD, 横方向）方向に切り出した. ここで熱接合部は $10 \mathrm{~mm}$ と した．熱接合部を中心に $180^{\circ}$ 開き，(株島津製作所製オー トグラフ $\mathrm{AG}-500 \mathrm{E}$ を用いて，つかみ具間距離 $50 \mathrm{~mm}$, 引張速度 $300 \mathrm{~mm} / \mathrm{min}$ で熱接合部が破断するまで引張り, その間の最大荷重をはく離強度とした。これらはJIS Z $1707 ： 1997$ に規定されたヒートシール開始温度の測定方 法に準じた。

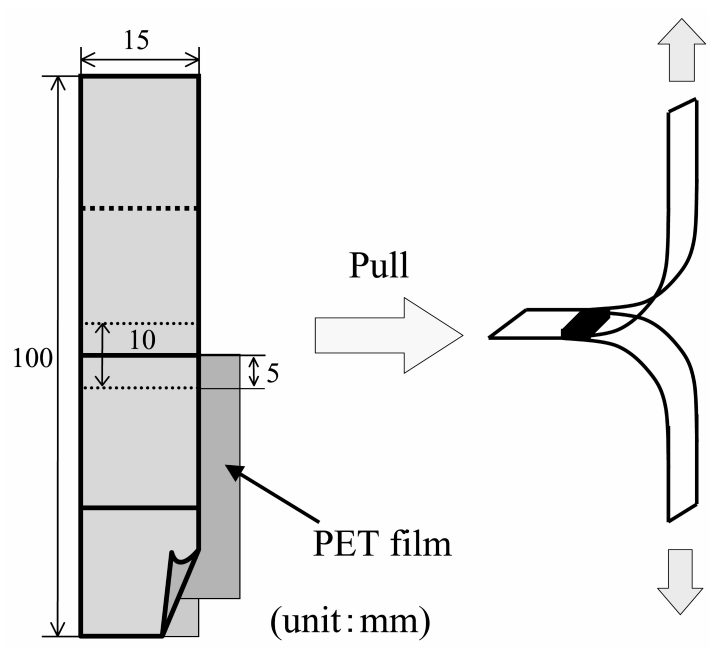

Fig. 3 Peel strength test method of the heat sealing part 


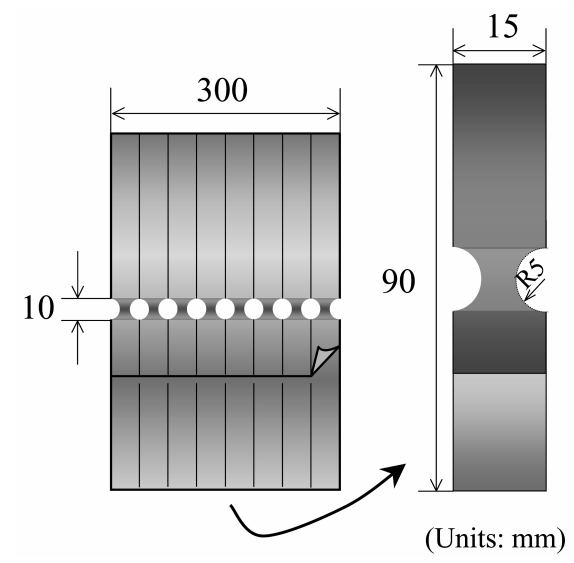

Fig. 4 Specimen of tensile test with circle notch

\section{4 円孔切り欠きを有する試験片を用いた引張試験 ${ }^{(3), 14)}$} 熱接合部そのものを, 圧力下で熱溶融させた成形加工中 に新たに形成される元の材料とは異なる特性をもつ成形加 工体と見なし，フィルム中に存在する熱接合部の引張特性 を測定するために，円孔切り欠きを有する試験片の引張試 験を行った。図 4 に試験片の形状を示す。幅 $15 \mathrm{~mm}$, 長 さ $90 \mathrm{~mm}$ の試験片を $\mathrm{MD}$ 方向㧍よび $\mathrm{TD}$ 方向に切り出し, 熱接合部で応力が集中して破断するように半径 $5 \mathrm{~mm}$ の円 孔切り欠きを設けた。引張試験は，インストロン侏製万能 試験機 4466 型を用いて，チャック間距離を $50 \mathrm{~mm}$ ，試験 速度を $20 \mathrm{~mm} / \mathrm{min}$ として引張試験を行った。得られた最 大荷重を最小断面積で除して引張強度とした。

\section{5 示差走查熱量測定（DSC）}

熱接合部の結晶構造を考察するために，示差走査熱量測 定（DSC）を行った。装置は PerkinElmer 製示差走査熱 量測定装置 PYRIS 1 DSC を用いた。測定条件は，窒素雾 囲気下 $(20 \mathrm{~mL} / \mathrm{min}),-20 \sim 200^{\circ} \mathrm{C}$ を $10^{\circ} \mathrm{C} / \mathrm{min}$ で加熱し た．温度校正には純度 $99.999 \%$ のインジゥム（融解温度 $156.60^{\circ} \mathrm{C}$ ) と純度 $99.999 \%$ 以上のスズ (融解温度 $231.88^{\circ} \mathrm{C}$ ) を用い，熱量校正はインジウムの融解熱 $(28.45 \mathrm{~J} / \mathrm{g})$ を 用いた。試験片は直径 $5.5 \mathrm{~mm}$ の鋭利な刃を持つパンチで 打ち抜き ( $2 \mathrm{mg}$ 程度), ウルトラミクロ電子天秤を用いて 正確に $1 \mu \mathrm{g}$ の単位まで秤量し, 開放型のアルミニウム試 料容器にクリンプし，封入した。

\section{6 顕微赤外分光分析}

フーリエ変換赤外分光光度計 (PerkinElmer 製 FT-IR, Spectrum One）に赤外顕微鏡（PerkinElmer 製赤外顕微 鏡, AutoIMAGE）を接続し，顕微赤外分光システムとし たものを用いた。試料は MICROM 製ミクロトーム HM 350 型を用いて厚さ $10 \mu \mathrm{m}$ に切り出し，透過法にて赤外吸 収スペクトルを得た．検出器には MCT（水銀一カドミウ ム一テルルの合金を素子とする半導体）を使用し，分解能 は $4 \mathrm{~cm}^{-1}$, 積算回数は 128 回とした.

\section{3 . 実 験 結 果}

\section{1 はく離試験}

各接合温度におけるはく離試験の結果を図 5 に示す。は く離強度は $\mathrm{TD}, \mathrm{MD}$ 方向ともに $120^{\circ} \mathrm{C}$ で $18 \mathrm{~N} / 15 \mathrm{~mm}$ 以 上に達し，ほほ一定の值を示した． $120^{\circ} \mathrm{C}$ 以上でのはく離

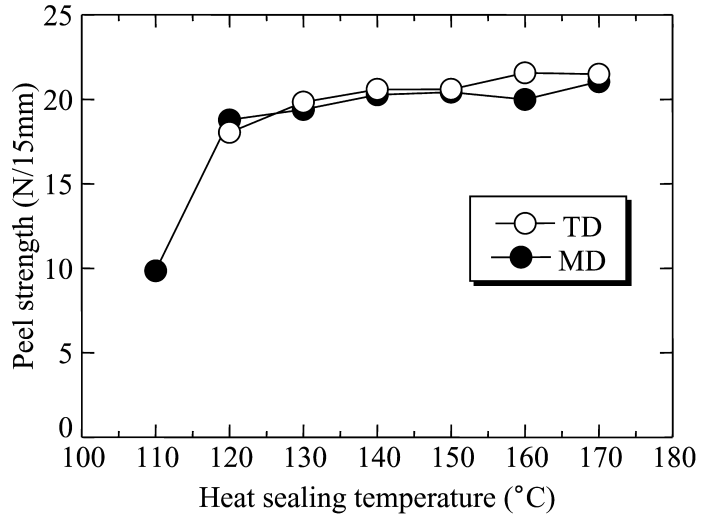

Fig. 5 Relationship between peel strength of TD, MD and heat sealing temperature $(\bigcirc: T D, O: M D)$

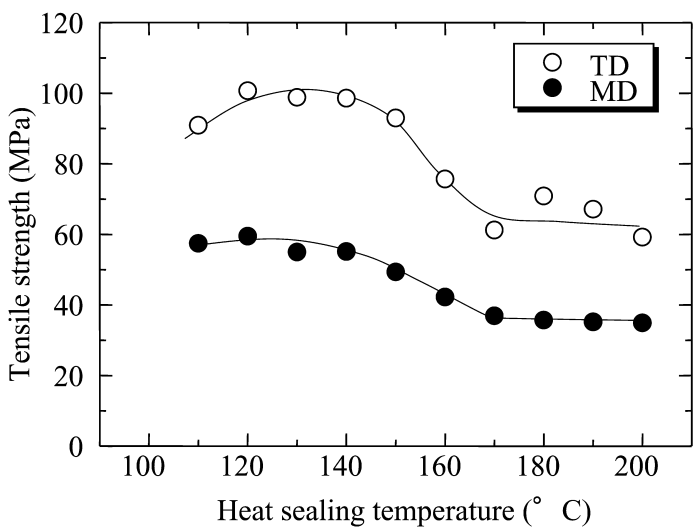

Fig. 6 Relationship between tensile strength and heat sealing temperature $(\bigcirc:$ TD, $\bigcirc:$ MD)

強度は，TD 方向が $\mathrm{MD}$ 方向より平均 $3.6 \%$ 高かった．目 視観察により， $120^{\circ} \mathrm{C}$ 以上では熱接合部と非熱接合部の境 界付近で破断したことが確認された.

\section{2 引張試験}

図 6 に TD，MD 方向における熱接合温度と引張強度を 示す. TD 方向が $\mathrm{MD}$ 方向に対して約 1.6 倍の引張強度を 示した. TD 方向では，熱接合温度 $120 \sim 140^{\circ} \mathrm{C}$ で引張強 度は最大となり, 熱接合温度 $160^{\circ} \mathrm{C}$ 以上では $20 \%$ 以上強 度が低下した．MD 方向においても，同様に引張強度は熱 接合温度 $120 \sim 140^{\circ} \mathrm{C}$ で最大值を示し, 熱接合温度 $150^{\circ} \mathrm{C}$ 以上で強度低下が認められた。目視観察により，試験片は 全て熱接合部で破断したことが確認された。

\section{3 示差走查熱量測定}

図 7 に CPP と OPP の 1 次加熱 DSC 曲線を示す。縦軸 は単位重量当りの熱流に換算した。 上方向が吸熱側である. 無延伸フィルムである $\mathrm{CPP}$ は $80^{\circ} \mathrm{C}$ 付近から低融点成分の 融解が始まり, 緩やかな吸熱ピークを示した。軸延伸フィ ルムの OPP は $120^{\circ} \mathrm{C}$ 付近から融解ピークが立ち上がり, $167^{\circ} \mathrm{C}$ 付近に非常に鋭いピークを示した。

図 8 にそれぞれの熱接合温度における熱接合部分の 1 次 加熱 DSC 曲線を示す。非熱接合部のラミネートフィルム の DSC 曲線には, $75^{\circ} \mathrm{C}$ 付近からピーク温度の $148^{\circ} \mathrm{C}$ 付近 にかけて CPP の融解に伴う緩やかな吸熱ピークと, $167^{\circ} \mathrm{C}$ 付近に OPP の融解に起因する鋭い吸熱ピークが認められ た。熱接合温度 $100^{\circ} \mathrm{C}$ では，CPP と OPP の融解ピークは 


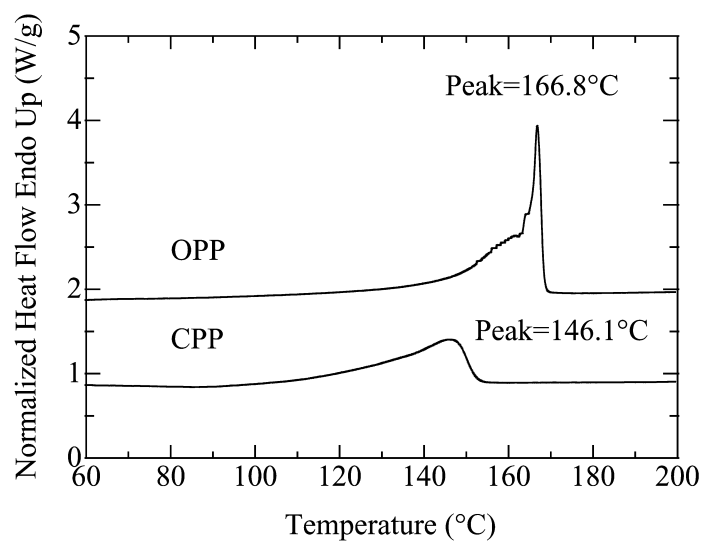

Fig. 7 DSC melting curves for CPP and OPP. Heating rate, $10^{\circ} \mathrm{C} / \mathrm{min}$

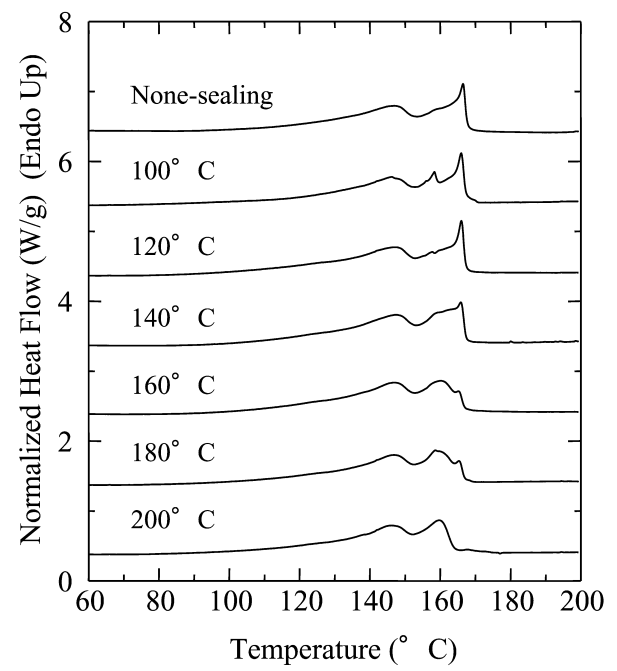

Fig. 8 DSC melting curves of heat sealing parts for $\mathrm{OPP} / \mathrm{CPP}$. Heating rate, $10^{\circ} \mathrm{C} / \mathrm{min}$

非熱接合部と同様の温度で認められ，OPP のピーク形状 はさらに鋭くなり, $158^{\circ} \mathrm{C}$ 付近に新たな吸熱ピークが観察 された。熱接合温度 $120^{\circ} \mathrm{C}$ では, OPP の融解に伴う $167^{\circ} \mathrm{C}$ 付近の吸熱ピークがより鋭くなり $158^{\circ} \mathrm{C}$ 付近のピークは 消失した。熱接合温度 $140^{\circ} \mathrm{C}$ では, $167^{\circ} \mathrm{C}$ 付近の融解ピー クが小さくなり, $160^{\circ} \mathrm{C}$ 付近に, 緩やかな吸熱ピークの存 在が認められた。これは $167^{\circ} \mathrm{C}$ 付近に見られた吸熱ピーク に関連する結晶が融解し，新たに結晶形成された領域が融 解していることを示している。熱接合温度 $160^{\circ} \mathrm{C}$ になる と, $167^{\circ} \mathrm{C}$ の吸熱ピークはさらに小さくなり, $160^{\circ} \mathrm{C}$ 付近 の吸熱ピークが支配的となった。熱接合温度 $180^{\circ} \mathrm{C}$ では熱 接合温度 $160^{\circ} \mathrm{C}$ と同様の DSC 曲線を示した。熱接合条件 $200^{\circ} \mathrm{C}$ では, $167^{\circ} \mathrm{C}$ 付近のピークはほとんど認められな かった.

各熱接合温度における融解熱と熱接合条件温度との関係 を図 9 に示す。融解熱は DSC 曲線のピーク面積から求め た。これらは OPP と CPP の融解熱の総和であり, 結晶化 度を表している．熱接合温度 $140^{\circ} \mathrm{C}$ まで融解熱は増加し， 明らかに熱接合温度 $140^{\circ} \mathrm{C}$ において，最大值を示し，その 後，温度が高くなるほど減少した。

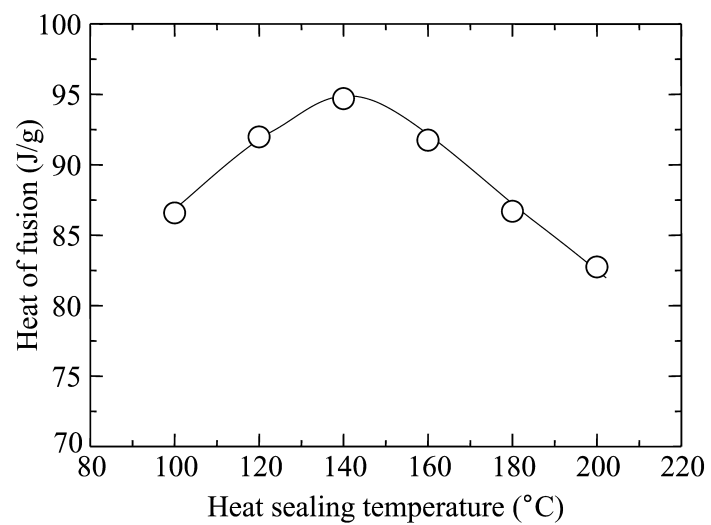

Fig. 9 Relationship between heat of fusion and heat sealing temperature

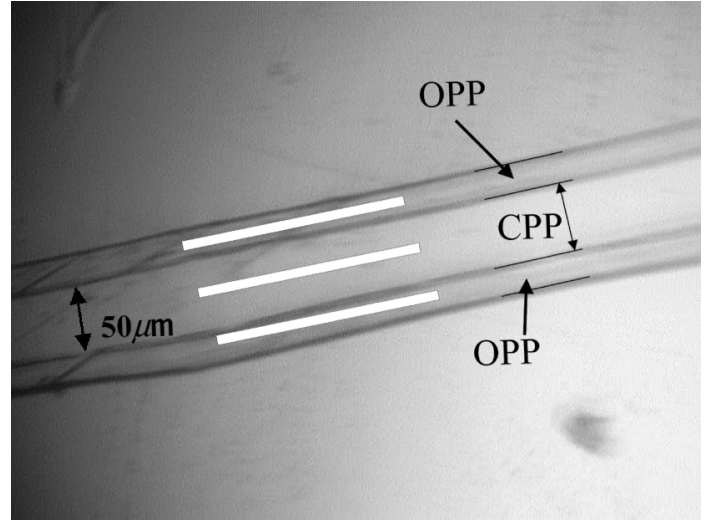

Fig. 10 Photomicrograph of OPP/CPP film (aperture $10 \mu \mathrm{m} \times 100 \mu \mathrm{m}$, heat sealing temperature at $\left.140^{\circ} \mathrm{C}\right)$

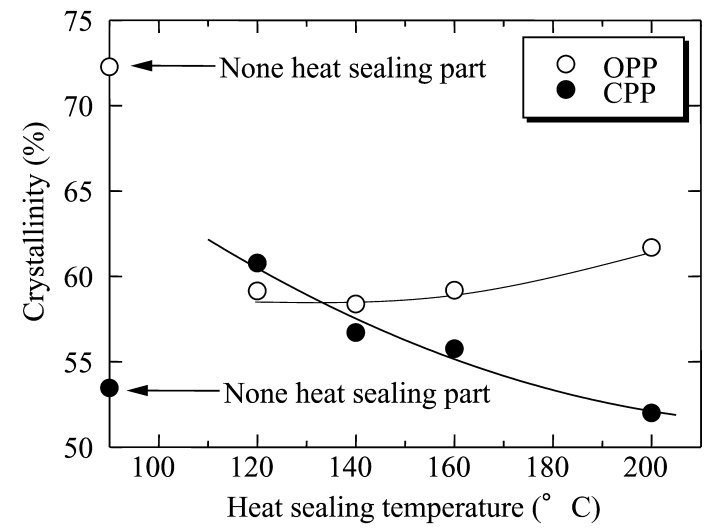

Fig. 11 Crystallinity of OPP and CPP in each heat sealing temperature

\section{4 顕微赤外分光測定}

顕微 FT-IR により OPP/CPP 試験片断面の各層におけ る赤外吸収スペクトルを測定し， CPP および OPP 層にお ける結晶化度を検討した。図 10 に熱接合温度 $140^{\circ} \mathrm{C}$ で熱 接合したフィルム断面の透過画像を示す. OPP と CPPが ラミネートされている状態と CPP 面が熱接合されて, CPP 面の境界がなくなり, $\mathrm{OPP} / \mathrm{CPP} / \mathrm{OPP} の 3$ 層構造のフィ ルムであることが明確に分かる。この断面の OPP 層と $\mathrm{CPP}$ 層の中央部を $10 \mu \mathrm{m} \times 100 \mu \mathrm{m}$ の範囲で赤外分光測 定した. 
結晶化度は，ポリプロピレンの結晶バンドである 998 $\mathrm{cm}^{-1}$ と非晶バンドである $974 \mathrm{~cm}^{-1}$ との吸光度の比を OPP と CPP について求めて算出した ${ }^{15)}$ １8) 。図 11 に各熱接合温 度における OPP と CPPのそれぞれの結晶化度を示す. OPP は非熱接合部の結晶化度が最も大きく, 熱接合によ り，結晶化度は小さくなった。 また，熱接合温度 $120^{\circ} \mathrm{C}$ か ら $160^{\circ} \mathrm{C}$ はほとんど結晶化度に変化はなく, $200^{\circ} \mathrm{C}$ で少し 増加することが分かった，CPPに関しては，熱接合によ り, 結晶化度が大きくなる接合条件があることが分かった. 熱接合条件 $120^{\circ} \mathrm{C}$ において結晶化度が最も大きくなり, $120^{\circ} \mathrm{C}$ から $160^{\circ} \mathrm{C}$ までの熱接合温度で $\mathrm{CPP}$ 単体の結晶化 度より大きくなった。 また, 熱接合温度 $200^{\circ} \mathrm{C}$ では結晶化 度が単体とほぼ同等になった。

\section{4. 考察}

はく離試験と熱接合部の引張試験から得られた引張強度 の傾向には差が見られた．特に，はく離試験において熱接 合温度 $120^{\circ} \mathrm{C}$ 以上でほぼ一定の強度を示した. 目視観察に より, $120^{\circ} \mathrm{C}$ 以上では熱接合部と非熱接合部の境界付近で 破断したことが確認されたことより，これは，この温度以 上でフィルム単体より熱接合部の強度が高くなり, 破壊個 所が熱接合部から非熱接合部へと変化したためであると考 えられる。そのため，はく離強度は熱接合部の特性を直接 的に示しているとは言い難く, 単に熱接合開始温度を示し ているだけに過ぎないと考えられる。 また，得られたはく 離強度と温度の関係は既にプラスチックデータブックに揭 載されている CPP の熱接合部のはく離試験の強度 ${ }^{19)}$ と温 度の関係と異なる傾向を示した. これは, 本試験では OPP と CPP のラミネートフィルムを使用していること, さら に成形方法，成形条件が異なるためと考えられる.

一方, 熱接合部の引張試験においては, 強度は熱接合温 度 $120^{\circ} \mathrm{C}$ から $140^{\circ} \mathrm{C}$ で最大值を示した. 破断はすべて熱接 合部で生じていることから，この強度はフィルム中に存在 する熱接合部の引張特性を示していると捉えられる。この 結果は, DSC の OPP/CPP の融解熱および IR 測定から得 られた $\mathrm{CPP}$ の結晶化度が $120^{\circ} \mathrm{C}$ から $140^{\circ} \mathrm{C}$ で最大值を示 したことと一致する。

図 12 に $\mathrm{OPP} / \mathrm{CPP}$ の TD 方向の引張強度に対する融解

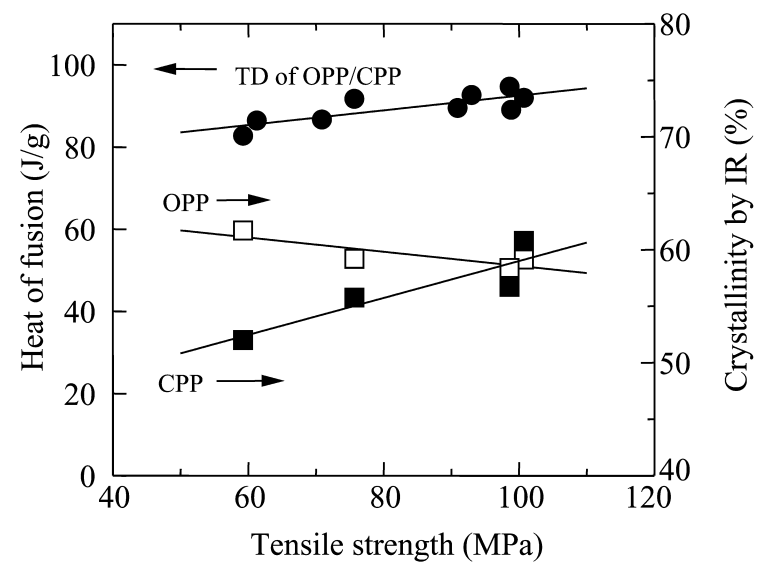

Fig. 12 Heat of fusion by DSC and crystallinity by infrared spectra as a function of tensile strength for the TD of the OPP/CPP
熱と赤外吸収スペクトルで得られた結晶化度との関係を示 す. OPP/CPP の融解熱が増加するに伴い引張強度が増加 することが明らかである. 赤外吸収スペクトルから得られ た OPP の結晶化度は引張強度が高いほど低くなり，一方， $\mathrm{CPP}$ の結晶化度は引張強度が高いほど高くなるという関 係があることがわかる，すなわち，CPP の結晶化度を高 くし, OPP の結晶化度を減少させず, 結晶化度の総和を 最大にする条件において引張強度が最大になるといえる.

CPP は，図 11 に示した通り熱接合温度 $120^{\circ} \mathrm{C}$ で結晶化 度が最大であった。非熱接合部の結晶化度よりも $120^{\circ} \mathrm{C} の$ 結晶化度の方が大きい值を示していることから，これは， CPP の再結晶化によるものと考えられる. それ以上の温 度では結晶化度が低下する傾向がみられた。すなわち，熱 接合温度 $120^{\circ} \mathrm{C}$ で $\mathrm{CPP}$ は部分融解し, 冷却により再結晶 化する. CPP が部分融解することにより，接合層になる CPP 層が 1 層になり，熱接合されるといえる，そして， この CPP 層の再結晶化による結晶化度が大きくなるほど 引張強度が高くなることになる。

OPP の結晶化度は熱接合温度 $120^{\circ} \mathrm{C}$ 以上でやや高くな る傾向を示した。しかし，ここでは, 結晶化度よりも, 図 8 に示した DSC 曲線における $167^{\circ} \mathrm{C}$ 付近に現れる鋭いピー クの挙動について考慮する必要がある.このピークは熱接 合温度 $140^{\circ} \mathrm{C}$ 以上で減衰し, 低温にシフトした。すなわち, 熱接合温度 $140^{\circ} \mathrm{C}$ では $167^{\circ} \mathrm{C}$ 付近で融解する結晶構造に変 化が現れたことを示しており，この結晶構造の変化が，熱 接合部の引張強度に影響を及ぼすと考えられる。このこと より, $167^{\circ} \mathrm{C}$ 付近のピークは OPP の二軸延伸に伴う結晶 配向に起因することが予測されるであろう。すなわち, 熱 接合温度 $140^{\circ} \mathrm{C}$ 以上では結晶配向が緩和し，それに伴い, 特に延伸方向の引張強度が低下することは容易に予測さ れ， $150^{\circ} \mathrm{C}$ 以上で引張強度が低下したこととよく一致する.

以上のことから, 引張強度が最大值を示した $120^{\circ} \mathrm{C}$ から $140^{\circ} \mathrm{C}$ の熱接合温度条件では, CPP の結晶化度が再結晶化 によって最大值を示すこと，OPP の二軸延伸に基づく配 向した結晶構造が存在することが言える.DSC 曲線にお ける鋭いピークで融解する結晶構造の影響が大きくないと いえる。したがって, CPP 層を部分融解させ, OPP 層の この結晶構造に大きく影響を及ぼさない熱接合温度におい て熱接合部の力学的特性が最大になることが示唆された. 換言すれば，CPP 層の融解と再結晶化および OPP 層の結 晶構造が熱接合部の力学的特性に大きく影響を及ぼすこと が明らかとなった。このことはさらに，はく離試験で評価 が不可能であった接合完了後の熱接合部の特性を評価でき たことを示している．OPP および CPP の結晶化特性を制 御することにより熱接合部の力学的特性を制御できること を示したといえる，具体的に言えば，熱接合時の冷却速度 を正確に制御し, CPP の再結晶化を制御すること, さら に, OPP の結晶構造と強度の関係を熱機械的特性測定な どにより詳細に把握し, 制御することで熱接合部の力学的 特性を向上することが可能であると考えられる.

\section{5. 結言}

本研究では, OPP/CPP ラミネートフィルムの熱接合部 のはく離強度, 引張特性, さらにその結晶性を示差走査熱 
量測定法，顕微赤外分光法により検討した？その結果，熱 接合部のはく離強度, 引張強度は OPP および CPP の結晶 性に依存し, CPP が融解, 再結晶し, かつ OPP の結晶配 向が大きく緩和しない条件に执いて引張強度が高くなるこ とが示された。

\section{参 考 文 献}

1）佐渡本克介：食品と科学，24（3），98（1982）

2) Spitz, J : Packaging, 31 (4), 69 (1986)

3 ) 渡辺一美, 足立和成, 村川秀一：成形加工，12（10）, $655(2000)$

4 ）玉井紀行：フードパッケージング，34(4)，144(1990)

5 ) Tall, S., Albertsson, A.-C. and Karlsson, S. : Polymers for Advanced Technologies, 12 (5), 279 (2001)

6 ) Schilperoord, T. : Packaging Technology and Science, 12 (6), 251 (1999)

7 ）平田浩二 : Packpia，39（5)，30（1995）

8 ) 新井康政, 高橋文男, 松本璋一, 溝口敬信, 滝島 豊 : 製品科学研究所研究報告，79，1（1977）

9 ）二瀬克規，島本 聡，高橋 賞，青木博之：非破壊検 查，45（12），874（1996）
10) C. Mueller, G. Capaccio, A. Hiltner, E. Baer : J. Appl. Poym. Sci., 70, 10, 2021 (1998)

11）野口悟司，中本 敦，船越文男，高階雅紀，中田精三, 田野保雄, 須藤禎子, 青木秀尚: 医科器械学, 70 (10)，545（2000)

12）社日本包装技術協会：包装材料の実際知識第 2 版, 206 （1993），東洋経済新報社

13）漕田泰以，藤田泰弘，辻井哲也，木下大輔：成形加工 シンポジア'99, 91（1999）

14）辻井哲也, 高橋一好, 森本光彦, 恩田宣彦, 藤田泰弘, 北川和男, 木下大輔, 䌸田泰以：第 36 回熱測定討論 会講演要旨集，36，98（2000）

15）錦田晃一，岩本令吉：赤外法による材料分析， 214 (1986)，講談社サイエンティフィク

16) Quynn, R. G., Riley, J. L., Yonung, D. A. and Hoether, H. D. : J. Appl. Polym. Sci., 2, 166 (1959)

17）Luongo, J. P. : J. Appl. Polym. Sci., 3, 302 (1960)

18）社日本分析化学会 高分子分析研究懇談会：新版高分 子分析ハンドブック，608（1995）

19）旭化成アミダス・プラスチックス編集部プラスチッ ク・データブック，379（1999），工業調査会 